\title{
Impact of social housing and social separation on haematological and physiological parameters in Syrian male hamsters
}

\author{
A. Kumari, Y. B. Rajeshwari², V. M. Patil2, R. R. $\operatorname{Yadav}^{2}$, S. M. Ali², G. S. Shaswath², S. K. \\ Bhandekar $^{3}$, A. Katiyar ${ }^{4}$, M. K. Durrani ${ }^{2}$ and P. Karan ${ }^{5}$
}

${ }^{1}$ Central Poultry Development Organization and Training Institute, Bangalore - 560 088, Karnataka, India; ${ }^{2}$ Dept of Livestock Production and Management, Veterinary College Hebbal, Bangalore - 560 024, Karnataka, India; ${ }^{3}$ Central Cattle Breeding Farm, Hessarghatta, Bangalore - 560 088, Karnataka, India; ${ }^{4}$ Central Poultry Development Organization, Nayapalli, Bhubaneswar - 751 012, Odisha, India; ${ }^{5}$ First Class Veterinary Hospital, Girihinda Chowk, Sheikhpura - 811 105, Bihar, India

\begin{abstract}
Syrian hamsters have been used as an animal model in different branches of medical sciences and veterinary sciences since 1930. This is partly because many aspects of their physiology are more similar to those of humans than many other laboratory animals. A socially bonded pair of hamster is the best animal model to study the circadian rhythm and anxiolytic drugs. A trial was conducted at Biogen Animal Facility, Bangalore to assess the haematological and physiological effects of Syrian hamsters in social housing versus social separation. Forty hamsters (20 males and 20 females) were randomly housed in pairs in 10 replicates and one control group with 10 replicates in polycarbonate cage with wire grid lids, corn cob litter material and soft nesting material. The social separation was not done in the control group till the end of the study. Blood collection from the orbital sinus was done at the end of social housing and at the end of social separation from male hamsters. Serum cortisol, total leukocyte count (TLC) count, differential count, platelet and packed cell volume were analyzed. The results indicated that socially separated males had significantly $(P \leq 0.05)$ higher serum cortisol levels than socially housed and control groups. There was higher significant difference $(\mathbf{P} \leq 0.01)$ in haemoglobin, TLC and PCV of socially separated males over socially housed males and control group males, whereas; there was no significant difference found in platelets count in all the groups. There was a marked reduction in the activity of socially separated male hamsters than socially housed.
\end{abstract}

Key words: Cortisol, Hamster, Social housing, Social separation, Stress

\section{INTRODUCTION}

Syrian hamsters have been used as an animal model in different branches of research in medical and veterinary sciences since 1930 (Valentine et al., 2012). Since many aspects of their physiology are more similar to those of humans than other laboratory animals (Ross et al., 2017). It has also been reported by Ross et al. (2017) that social housing followed by social separation causes anxiety-induced anorexia and reductions in body weight selectively in females. It has also been reported that socially bonded pair of hamsters are the best animal model to study the circadian rhythm and modern anxiolytic drugs (Shannonhouse,
2017). In addition, hamsters, like humans, are dual secretors of cortisol and corticosterone (Solomon et al., 2011). Cortisol is more labile in response to circadian rhythm and different types of stress like managemental and environmental (Clifford and Summons, 2017). This pattern of response is in marked contrast to most laboratory rodents, which primarily secrete corticosterone, and suggests that hamsters are an ideal species for stress/ antidepressant drug research. The objective of this experiment was to determine the haematological and physiological effects of Syrian male hamsters in social housing as compared to social separation. 


\section{MATERIALS AND METHODS}

A trial was conducted at Biogen Animal Facility, Bangalore, in the year 2018 with an objective to assess the haematological and physiological effects of Syrian hamsters in social housing as compared to social separation. Forty hamsters (20 males and 20 females) in pairs were randomly housed in 10 replicates as $T_{1}$ (social housed males) for four weeks, whereas same males considered as $\mathrm{T}_{2}$ after social separation from females. The control group $\left(\mathrm{T}_{3}\right)$ with 10 replicates in polycarbonate cages $(23 \times 43 \times 20$ $\mathrm{cm}$ ) with wire grid lids, corn cob litter material and soft nesting material. The social separation was not done in the control group till the end of the trial. Feed-in pellet form and reverseosmosis-purified water was made available ad libitum. The room was maintained on a 14:10 light: dark cycle at $23 \pm 3^{\circ} \mathrm{C}$, as it is mandatory with hamsters to maintain the photoperiodic control on gonadal hormones. All procedures were approved by the Institutional Animal Ethical Care Committee and were in accordance with the standards outlined in the CPCSEA. Male hamsters were separated from each cage after 4 weeks and reared in isolation for another 4 weeks except in the control group paired hamsters.

The hamsters were anesthetized by isoflurane inhalation anesthetic and $1 \mathrm{~mL}$ blood was collected from the orbital sinus (Popesko et al., 1992) on the last day of social housing and social separation of the trail. Serum cortisol was measured with an enzyme-linked immunosorbent assay following the manufacturer's instructions (Sigma-Aldrich). The differential count like neutrophils, lymphocytes, eosinophils, monocytes, myelocytes, basophils and band form and haemoglobin, total leukocytes count (TLC) count, platelet count and packed cell volume (PCV) was measured by calibrated SYSMEX pocH-100i fully automated analyzer.

Statistical analysis method: The descriptive statistics for haematological and physiological effects were analyzed using SPSS version 16.0. One way ANOVA was carried out to study the impact of social housing and social separation on cortisol, TLC count, differential count, haemoglobin, platelet and packed cell volume in Syrian male hamsters.

\section{RESULTS}

Impact of social housing and social separation on cortisol, total count, differential count, platelet and packed cell volume in Syrian hamsters are given in Table 1 . The mean haemoglobin (\%), TLC count (cells/ $\mu \mathrm{L})$, platelet count (lakhs/ $\mu \mathrm{L})$ and PCV (\%) of socially housed group hamster males were 16.9, 4270, 4.16 and 47.59 respectively, whereas, it was $15.79,5220,4.78$ and 43.90 respectively in socially separated group hamster males. There was a higher significant difference $(\mathrm{P} \leq 0.01)$ in haemoglobin, total count and PCV of socially separated males over socially housed males and control group males whereas, there was no significant difference found in platelet count in all the groups. The average neutrophils (\%), lymphocytes $(\%)$ and eosinophils (\%) of socially housed hamster males were 70.2, 25.3 and 2.2 respectively; whereas it was $76.5,21.0$ and 1.2 respectively in socially separated hamster males. There was higher significant difference $(\mathrm{P} \leq 0.01)$ in average neutrophils $(\%)$, lymphocytes $(\%)$ and eosinophils $(\%)$ of social separated males over socially housed males and control group males. The present study did not find monocytes, myelocytes and basophils in Syrian hamster blood; however band form was in the normal range in all the groups. The mean serum cortisol $(\mu \mathrm{g} / \mathrm{dL})$ of socially housed and socially separated male hamsters was 0.750 and 1.132 , respectively. There was higher significant difference $(\mathrm{P} \leq 0.05)$ in mean serum cortisol $(\mu \mathrm{g} / \mathrm{dL})$ of social separated males over socially housed males and control group males.

\section{DISCUSSION}

The haematological values were in the normal range as per previous studies (Moore, 2000; Provencher et al., 2010; Smith et al., 2010; Clifford, 2017), however there was no previous research work done on the impact of 
Table 1. Comparative statement of haematological parameters and serum cortisol $(\mu \mathrm{g} / \mathrm{dL})$ of Syrian hamsters in socially housed and socially separated groups

\begin{tabular}{lllll}
\hline Hematology parameters & Social housing & Social separation & Control & P Value \\
\hline Hemoglobin $(\%)$ & $16.9^{\mathrm{A}} \pm 0.27$ & $15.79^{\mathrm{B}} \pm 0.25$ & $16.2^{\mathrm{A}} \pm 0.24$ & 0.008 \\
TLC count (cells/ $\mu \mathrm{L})$ & $4270^{\mathrm{B}} \pm 62.95$ & $5220^{\mathrm{A}} \pm 208.24$ & $4300^{\mathrm{B}} \pm 75.25$ & 0.007 \\
Platelet count $($ lakhs/ $\mu \mathrm{L})$ & $4.16 \pm 0.26$ & $4.78 \pm 0.19$ & $4.25 \pm 0.31$ & 0.061 \\
PCV $(\%)$ & $47.59^{\mathrm{B}} \pm 0.75$ & $43.9^{\mathrm{A}} \pm 0.63$ & $46.52^{\mathrm{B}} \pm 0.65$ & 0.008 \\
Neutrophils $(\%)$ & $70.2^{\mathrm{B}} \pm 1.10$ & $76.5^{\mathrm{A}} \pm 0.54$ & $71.2^{\mathrm{B}} \pm 1.25$ & 0.004 \\
Lymphocytes (\%) & $25.3^{\mathrm{A}} \pm 0.96$ & $21.0^{\mathrm{B}} \pm 0.44$ & $25.6^{\mathrm{A}} \pm 0.12$ & 0.009 \\
Eosinophils (\%) & $2.2^{\mathrm{A}^{\mathrm{A}} \pm 0.14}$ & $1.2^{\mathrm{B}} \pm 0.14$ & $2.1^{\mathrm{A}} \pm 0.08$ & 0.007 \\
Monocytes (\%) & 00 & 00 & 00 & - \\
Myelocytes (\%) & 00 & 00 & 00 & - \\
Basophils $(\%)$ & 00 & 00 & 00 & - \\
Band form $(\%)$ & $1.1 \pm 0.10$ & $1 \pm 0.0$ & $1 \pm 0.0$ & 0.125 \\
Serum Cortisol $(\mu \mathrm{g} / \mathrm{dL})$ & $0.750 \pm 0.21^{\mathrm{b}}$ & $1.132 \pm 0.29^{\mathrm{a}}$ & $0.319 \pm 0.04^{\mathrm{c}}$ & 0.026903 \\
\hline
\end{tabular}

A, B - Means bearing different superscripts within rows differ significantly* (Pd"0.01)

a, $b$ - Means bearing different superscripts within rows differ significantly* (Pd"0.05)

social housing and social separation on haematological parameters in Syrian male hamsters. Provencher et al. (2010) reported about rare occurrence of monocytes, basophils and myelocytes. Band forms are generally observed during inflammation in Syrian hamster (Moore, 2000). When male hamsters were separated into individual cages after previous paired housing during development, the animals may experience some stress due to the change in housing. The results of the serum cortisol in this study are in agreement with (Meisel et al., 1990) who reported similar findings. In contrast to this, Ross et al. (2017) reported socially housed and socially separated Syrian hamsters had similar serum cortisol levels. Perhaps the most surprising conclusion that can be drawn from the present data is that male Syrian hamster is not able to adapt well to social isolation, however Ross et al. (2017) concluded that both male and female Syrian hamsters were adapted well in social housed and social separation. Lindstrom et al. (2015) reported that acute stress in hamsters results in elevated serum cortisol but normal neutrophil/lymphocyte ratio, whereas distress decreases the serum cortisol concentrations with an elevated neutrophil/ lymphocyte ratio. However, other studies reported that neutrophilia and lymphopenia were seen in chronically stressed laboratory animals. Yoganathan et al. (1998) reported that stress induced by feed modification enhances cholesterol and triglyceride level in group housed hamsters than individually housed hamsters, although Smith et al. (2010) found a similar effect in young Syrian hamsters. Weinberg and Wong, (1986) reported that housing hamsters in unfamiliar environment will increase cortisol level whereas, KingHerbert et al. (1997) found no difference in serum cortisol level in hamsters housed in unfamiliar environment. Huhman et al. (1991) concluded that male hamsters housed with ovariectomized female hamster will induce significant increase in blood adrenocorticotropic hormone (ACTH) and cortisol level.

The result of the present study indicates that even though Syrian hamsters may be naturally solitary animals, they are not able to adapt to social isolation in the laboratory environment. The separation causes stress in the male hamsters, which makes this animal as a good model for behavioral studies for humans affected with a mood disorder. It is also evident that socially separated males have significantly increased serum cortisol level and significant deviation of haematological parameters than socially housed male Syrian hamsters. 
Conflict of interest: Authors have no conflict of interest in this study.

Author's contribution: AK: Has substantial contribution to the conception and design, the acquisition of data, statistical analysis of data and interpretation of the results or drafting or critically revising the manuscript; YBR \& VMP: Were mentoring and drafting or critically revising the manuscript; RRY, SMA, SGS, SKB, AKR, MKD and PK: Had substantial

\section{REFERENCES}

Clifford CB and Simmons JH, 2017. The Clinical Chemistry of Laboratory Animals. In Chapter: The Laboratory Hamster. 3rd edn., CRC Press, USA, pp 1-16

Huhman KL, Moore TO, Ferris CF, Mougey EH and Meyerhoff JL, 1991. Acute and repeated exposure to social conflict in male golden hamsters: increases in plasma POMC-peptides and cortisol and decreases in plasma testosterone. Horm Behav, 25(2): 206-216 doi: 10.1016/0018-506x(91)90051-i

King-Herbert AP, Hesterburg TW, Thevenaz PP, Hamm Jr TE, Moss OR et al., 1997. Effects of immobilization restraint on Syrian golden hamsters. Lab Anim Sci, 47(4): 362-366

Lindstrom NM, Moore DM, Zimmerman K and Smith SA, 2015. Hematologic assessment in pet rats, mice, hamsters, and gerbils: blood sample collection and blood cell identification. Vet Clin North Am Exot Anim Pract, 18(1): 21-32, doi: 10.1016/ j.cvex.2014.09.004

Meisel RL, Hays TC, Del Paine SN and Luttrell VR, 1990. Induction of obesity by group housing in female Syrian hamsters. Physiol Behav, 47(1): 815-817, doi: 10.1016/0031-9384(90)90002-1

Moore DM, 2000. Hematology of the Syrian (golden) hamster (Mesocricetus auratus).In: Feldman BF, Zinkl JG, Jain NC, editors. Schalm's Veterinary Hematology. $5^{\text {th }}$ edn., Philadelphia, Lippincott Williams and Wilkins, pp 1115-1119

Popesko P, Rajtová V and Horák J, 1992. A Colour Atlas of the Anatomy of Small Laboratory Animals: Saunders Publication, United Kingdom. Available at http://vlib.kmu.ac.ir/kmu/handle/kmu/90417 [Accessed on 15.07.2021]

Provencher Bollinger A, Everds NE and Zimmerman KL, 2010. Hematology of laboratory animals. In: Weiss DJ, Wardrop KJ, editors. Schalm's veterinary hematology. Philadelphia: Lippincott Williams and contribution to the conception and design, the acquisition of data and statistical analysis of data.

\section{ACKNOWLEDGEMENTS}

Authors are thankful to Mr. Francis, Managing Director of Biogen Laboratory Animal House, Attibele, Bangalore and Dr. Y. B. Rajeshwari, Retd. Professor and Head, Department of LPM, Veterinary College, Bangalore, for providing facilities and guidance for conducting the above research trial.

Wilkins, pp 852-62. Accessed at https:// www.vetexotic.theclinics.com/article/S10949194(14)00060-7/pdf\#back-bib3 [Accessed on 15.07.2021]

Ross AP, Norvelle A, Choi DC, Walton JC, Albers HE et al., 2017. Social housing and social isolation: impact on stress indices and energy balance in male and female Syrian hamsters (Mesocricetus auratus). Physiol Behav, 177: 264-269, doi: 10.1016/j.physbeh.2017.05.015

Shannonhouse JL, 2017. Syrian Hamsters as a Clinically Relevant Model for Mood Disorders. Doctoral dissertation, Texas A \& M University. Available electronically from https : / /hdl .handle .net / $1969.1 / 161286$ [Accessed on 15.07.2021]

Smith SA, Zimmerman KL and Moore DM, 2010. Hematology of the Syrian (golden) hamster. In Schalm's Veterinary Hematology. Lippincott Williams and Wilkins, Philadelphia, pp 904-909

Solomon MB, Sakai RR, Woods SC and Foster MT, 2011. Differential effects of glucocorticoids on energy homeostasis in Syrian hamsters. Am J Physiol Endocrinol Metab, 301(2): E307-E316, doi: 10.1152/ajpendo.00009.2011

Valentine H, Daugherity EK, Singh B and Maurer KJ, 2012. The experimental use of Syrian hamsters. In The Laboratory Rabbit, Guinea Pig, Hamster, and Other Rodents. Academic Press, pp 875-906

Weinberg J and Wong R, 1986. Adrenocortical responsiveness to novelty in the hamster. Physiol Behav, 37(5): 669-672, doi: 10.1016/00319384(86)90170-8

Yoganathan S, Wilson TA and Nicolosi RJ, 1998. Housing conditions effect plasma lipid concentrations and early atherogenesis independent of treatment in hamsters. Nutr Res, 18(1): 83-92, doi: 10.1016/S0271-5317(97)00202-9

Received - 18.07.2021, Accepted - 06.11.2021, Published-01.12.2021

Section Editor: Dr. A. K. Patra, Associate Editor 